\title{
Commentary: Are we really operating on advanced stage non-small cell lung cancer?
}

\author{
Dana Ferrari-Light, DO, MPH, and Robert J. Cerfolio, MD, MBA, FACS, FCCP
}

\author{
From the Department of Cardiothoracic Surgery, New York University Langone Health, New York, NY. \\ Disclosures: Dr Cerfolio discloses relationships with Bovie, Community Health Services, Covidien/Medtronic, \\ C-SATS, Davol/Bard, Ethicon, Google/Verb, Intuitive Surgical, KCI/Acelity Company, Myriad Genetics, \\ Pinnacle, ROLO-7 Consulting Firm, and TEGO Corporation. Dr Ferrari-Light has nothing to disclose with re- \\ gard to commercial support. \\ Received for publication Oct 16, 2018; revisions received Nov 26, 2018; accepted for publication Nov 28, 2018; \\ available ahead of print Jan 18, 2019. \\ Address for reprints: Robert J. Cerfolio, MD, MBA, FACS, FCCP, New York University Langone Health, 550 1st \\ Ave, 15th Floor, New York, NY 10016 (E-mail: Robert.Cerfolio@nyumc.org). \\ J Thorac Cardiovasc Surg 2019;157:1631-2 \\ $0022-5223 / \$ 36.00$ \\ Copyright (C) 2018 by The American Association for Thoracic Surgery \\ https://doi.org/10.1016/j.jtcvs.2018.11.088
}

\section{The answer is yes, and the reality is-we already} have.

Immunotherapy and increasingly discovered targeted chemotherapeutic agents directed against actionable mutations have resulted in longer survival of patients with advanced stage non-small cell lung cancer (NSCLC). This situation has surgeons increasingly asked by our informed medical colleagues to perform resection for selected patients with persistent pulmonary disease and initial stage IIIA, IIIB, and IV NSCLC. But is this effective, and does it add patient value or only to our contribution margin?

There have been several articles published recently on the outcomes and survival after surgery for stage IV NSCLC. In 2017 Chikaishi and associates ${ }^{1}$ published a retrospective review including 38 patients with stage IV NSCLC who underwent resection of the primary lesion, with an overall survival of $29 \%$ at a median of 725 days-almost 2 years. A similar retrospective study in 2017 by Yamaguchi and colleagues ${ }^{2}$ showed that of 23 patients with stage IV NSCLC undergoing curative-intent surgery, 17 had recurrence (13 distal, 3 local or intrathoracic, 1 both sites). Encouragingly, they found a 5year overall survival of $41.7 \%$.

In this issue of the Journal, David and colleagues ${ }^{3}$ present a novel surgical selection score that attempts to predict which patients with advanced NSCLC will benefit from surgical resection. Their analysis shows an almost 3-fold median survival time (35.5 months vs 12.9 months) for highly selected patients treated with surgical therapy. More significantly, the hazard of death was still 2 times higher for patients with stage IIIA, stage IIIB, and stage IV disease in the upper quartile of the worst surgical selection score who did not receive surgery relative to surgical patients, despite adjustment for this higher risk.

Obviously, more data are needed, given the limited numbers of patients who received pulmonary resection in

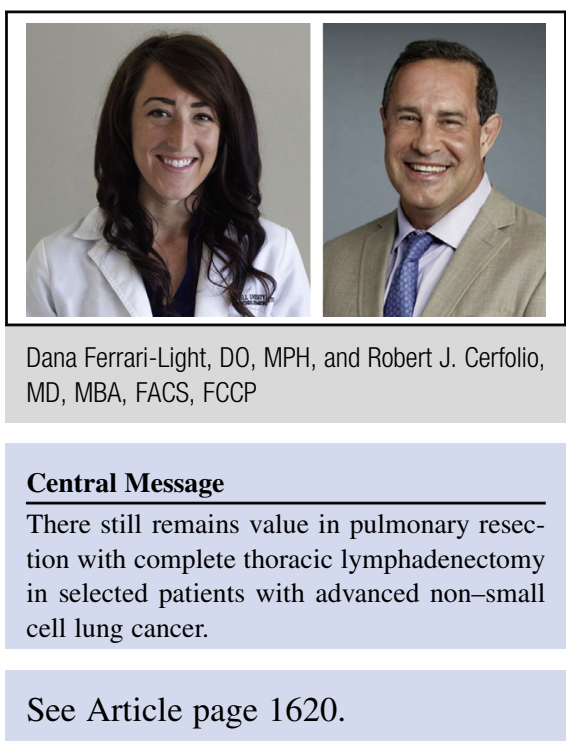

each of these advanced stage groups. This article is not yet granular enough to tell us what the specific patient-, tumor-, and stage-specific characteristics are required to provide true benefit by adding surgical resection to their care. Most of us would agree that if a pneumonectomy is required to deliver an $\mathrm{R} 0$ resection, then pulmonary resection should not be offered. Other details are lacking, however, including such data as pulmonary function test results, functional capacity, tumor biology, and even the patient's preferences and quality of life - much of which is not available in the National Cancer Database, which was used in this study. One must ask then whether these questions are fully answered currently, or whether further studies and different data sets are required.

Regardless, the take-home message of David and colleagues ${ }^{3}$ is clear, and it is an important one given the current trend away from surgery in advanced stage NSCLC, partly because of the widespread and inaccurate quoting of studies such as the recent PACIFIC Trial. ${ }^{4,5}$ The take home message is: There still remains value for pulmonary resection with complete thoracic lymphadenectomy in selected patients with advanced stage NSCLC.

\section{References}

1. Chikaishi Y, Shinohara S, Kuwata T, Takenaka M, Oka S, Hirai A, et al. Complete resection of the primary lesion improves survival of certain patients with stage IV non-small cell lung cancer. J Thorac Dis. 2017;9:5278-87. 
2. Yamaguchi M, Edagawa M, Suzuki Y, Toyozawa R, Hirai F, Nosaki K, et al. Pulmonary resection for synchronous M1b-cstage IV non-small cell lung cancer patients. Ann Thorac Surg. 2017;103:1594-9.

3. David EA, Andersen SW, Beckett LA, Melnikow J, Clark JM, Brown LM, et al. Survival benefits associated with surgery for advanced non-small cell lung cancer. J Thorac Cardiovasc Surg. 2019;157:1620-8.
4. Antonia SJ, Villegas A, Daniel D, Vicente D, Murakami S, Hui R, et al; PACIFIC Investigators. Durvalumab after chemoradiotherapy in stage III non-small-cell lung cancer. N Engl J Med. 2017;377:1919-29.

5. Antonia SJ, Villegas A, Daniel D, Vicente D, Murakami S, Hui R, et al; PACIFIC Investigators. Overall survival with durvalumab after chemoradiotherapy in stage III NSCLC. N Engl J Med. September 25, 2018 [Epub ahead of print]. 